\begin{tabular}{|c|l|}
\hline Title & $\begin{array}{l}\text { Effects of fine sediment accumulation on the redd environment and the survival rate of masu sal mon (Oncorhynchus } \\
\text { masou) embryos }\end{array}$ \\
\hline Author(s) & Y amada, Hiroyuki; Nakamura, Futoshi \\
\hline Citation & $\begin{array}{l}\text { Landscape and Ecological Engineering, 5(2), 169-181 } \\
\text { https:/doi.org/10.1007/311355-009-0065-8 }\end{array}$ \\
\hline Issue Date & 2009-07 \\
\hline Doc URL & http://hdl.handle.net/2115/39028 \\
\hline Rights & The original publication is available at www.springerlink.com \\
\hline Type & article (author version) \\
\hline File Information & LEE5-2_p169-181.pdf \\
\hline
\end{tabular}

Instructions for use 
Journal title: Landscape and Ecological Engineering

Article ID: LEE135

Type of Paper: original paper

\title{
Effects of fine sediment accumulation on the redd environment and the survival rate of masu salmon (Oncorhynchus masou) embryos
}

\author{
Hiroyuki Yamada and Futoshi Nakamura
}

Graduate School of Agriculture, Hokkaido University, Sapporo, Japan

Running head: Effect of fine sediment on masu salmon embryo

Corresponding author: Hiroyuki Yamada

Address: Environmental Informatics Lab., Graduate School of Agriculture, Hokkaido University, Sapporo, 060-8589, Japan

Phone: +81-11-706-4183 / Fax: +81-11-706-2494

E-mail: hiroyama@env.agr.hokudai.ac.jp

Grants:

1) Grants in Aid for Scientific Research from the Ministry of Education, Science and Culture (Nos. 13460061, 14380274, 14506039, 17780242)

2) Fund provided by Technology Research Centre for Riverfront Development

3) River Environment Fund (REF) of the Foundation of River and Watershed Environment Management (FOREM)

4) Workshop Fund provided by Japan Society of Erosion Control Engineering 
2 In recent years, fine sediment, produced by run-off associated with forestry activity and 3 agricultural development that accumulates on riverbeds, has exerted a deleterious influence on

4 lotic ecosystems. This study examined the Oroennukibetsu River, a tributary of the Nukibetsu

5 River, which has been affected by high loads of suspended sediments. Effects of accumulation

6 of fine sediment on the survival rate of masu salmon embryo and also on the redd environment

7 (permeability and intragravel dissolved oxygen concentration) were quantified through a field

8 experiment. Results show that the interchange of DO between intragravel and surface water was

9 not affected directly by permeability or the accumulated fine sediment, and that intragravel flow

10 rates can be an important factor controlling embryo survival. A decrease in permeability

11 associated with accumulation of fine sediment lowered the survival rate of embryos by

12 suffocation because the flux of DO that should be supplied to the embryo was severely limited.

13 This situation might be created by the combined effects of an accumulation of fine sediment on

14 the redd and a low DO concentration in the surface water because the DO concentration almost

15 coincided with the intragravel DO.

16

17 Keywords: dissolved oxygen, eyed egg, flux, hyporheic, pool-riffle 


\section{Introduction}

Sediment pollution has become a serious issue throughout the world, and especially in East Asian countries, since the latter twentieth century. Generally, it has resulted from land use activities such as farmland development (e.g. Allan et al. 1997; Nakamura et al. 1997; Nakamura and Yamada 2005), forestry activities (e.g. Platts et al. 1989; Nakamura et al. 2004), mining (Hellawell 1986), and road construction (e.g. Barton 1977; Extence 1978; Cline et al. 1982). Such pollution has been defined as fine sediments, with sand, silt, and/or clay particles smaller than $2 \mathrm{~mm}$. It imparts marked adverse effects on human society and aquatic ecosystems (Waters 1995). Particularly, excessive accumulations of fine sediment on riverbeds deleteriously influences habitats of fish, benthos, and periphyton (e.g. Berkman and Rabeni 1987; Wood and Armitage 1997; Watanabe et al. 2001; Yamada and Nakamura 2002; Nakamura et al. 2008).

In particular, embryos and alevins of salmonids reside in riverbeds and are therefore subject to detrimental effects of fine sediment accumulation on the riverbed. Accordingly, over the past half century, the relation between embryo survival and fine sediment accumulation has been examined (e.g. Wickett 1954; McNeil and Ahnell 1964; Tappel and Bjornn 1983; Greig et al. 2005). Successful incubation of salmonid embryos and emergence of fry are highly dependent upon extragravel and intragravel characteristics (chemical, geomorphological, and hydrological) of the spawning grounds (Chapman 1988; Greig et al. 2007). These include dissolved oxygen (DO) concentration, water temperature, substrate size, the channel gradient and configuration, water depth above the redd, surface water discharge and current velocity, permeability and porosity of the gravel deposit, and intragravel velocity in the redd. Chapman (1988) noted that salmonid embryos can be mortally affected by changes in more than one characteristic. For example, the accumulation of fine sediment engenders depletion of intragravel dissolved oxygen concentration because the fine sediment lowers the permeability sufficiently to prevent interchange between surface and subsurface water. The consequent decrease in intragravel flow rates might impair the supply and circulation of water in the redd directly. This situation occurs depending on the characteristics of each salmonid embryo, grain 
1 size of the fine sediment, and water chemistry in the study basin. However, few attempts have

2 been made to explain the mechanisms involved in fine sediment and survival of embryos by

3 examining all physicochemical controlling factors (e.g. Malcolm et al. 2003b; Greig et al. 2005).

4 Moreover, these studies were conducted with very few sampling points and multipoint sampling.

5 Consequently, hydrochemical variation of the hyporheic zone could not be established as it was

6 in Soulsby et al. (2001). In addition, previous studies were conducted for salmonids distributed

7 in North America and England, but very few studies have specifically addressed masu salmon

8 (Oncorhynchus masou), which is widely distributed in far eastern Asia.

\section{Materials and Methods}

\section{Study site}

The Nukibetsu River Basin in south-central Hokkaido, northern Japan, is cultivated intensively, primarily for wheat, potato, and pulse crops (Fig. 1). The basin geology consists of volcanic products and their underlying Neogene volcanic rock; many slope failures have occurred along the pyroclastic flow plateau (Sato et al. 2002). Previous reports have described that suspended sediment discharge and fine sediment accumulation on riverbeds have increased concomitantly with advancing agricultural development (Hokkaido Forestry Research Institute et al. 1998, 1999, 2000; Murakami et al. 2001). Currently, the annual wash load exceeds $10^{10}$ $\mathrm{mg} \mathrm{km} \mathrm{yr}^{-1}$ at the river mouth (Sato et al. 2002). Therefore, an increase in the fine sediment load and accumulation on the riverbed are considered to have caused the rapid decline of the masu salmon population (Hokkaido Forestry Research Institute et al. 1998) as well as the number of species and population of the macrobenthos (Nagasaka et al. 2000). 
2 a tributary of the Nukibetsu River. The catchment of the Oroennukibetsu River encompasses an 3 area of $22 \mathrm{~km}^{2}$, with a channel length of $13 \mathrm{~km}$ and a riverbed slope of $1 / 32$ (Fig. 1). Compared 4 to the Nukibetsu River, the Oroennukibetsu River has a low level of accumulated sediment 5 (Murakami et al. 2001); more masu salmon redds have been observed (Hokkaido Forestry 6 Research Institute et al. 1998).

A study section with numerous masu salmon redds was selected at a part of the river 8 situated 6-8 $\mathrm{km}$ from its confluence with the Nukibetsu River. A landslide scar exists in the 9 middle reach of the section, which is considered to be the primary source of fine sediment downstream from this point. Consequently, a large amount of fine sediment accumulated in the 11 lower reaches of the study section.

Experimental period and installation of artificial redds

Masu salmon spawn in the redd on the tail of a pool in early autumn, during September - early October, in Hokkaido, Japan. The spawned eggs hatch when their cumulative temperature reaches almost $450^{\circ} \mathrm{C}$ (Kato 1991). The embryo and fry inhabit the redds for almost half a year until they rise into the stream currents in spring: early May (Mayama 1992). In the study reach, spawning behaviour was observed in mid-September in 1999. Our experiment was begun from October 1 to maintain consistency with the natural growth stage of the embryo. Then, to evaluate the effect on egg survival, we used eyed eggs (collection, September 10, 1999; cumulative temperature, $267.2^{\circ} \mathrm{C}$ ), which had been sampled from pond-reared masu salmon originated in the Shiribetsu River at Mori stations of the Hokkaido Fish Hatchery. Furthermore, we set the experiment period for almost 3 weeks (Oct. 1-23, 1999) to reach to the cumulative temperature level of $450^{\circ} \mathrm{C}$, which is sufficient for embryos to hatch completely. In the study river basin, the water discharge increases in spring (March - early May) because of snow-melt, and occasionally in summer or in autumn because of typhoons or storms. 
(Fig. 2).

Regarding the physical spawning environment of masu salmon, it was reported that the mean current velocity at the tails was $50 \mathrm{~cm} / \mathrm{s}$, and that the ranges of water depth, gravel size, mound length, and width were, respectively, $9-13 \mathrm{~cm}, 0.5-2.5 \mathrm{~cm}, 141-168 \mathrm{~cm}$, and $85-100 \mathrm{~cm}$ (Sugiwaka et al. 1999). To satisfy these natural spawning conditions, eight tails were selected in the study reach (Table 1; Fig. 1). Furthermore, the number of egg pockets in a redd was reported as 1-6; the mean number of eggs was $323(15-1080)$ in an egg pocket (Sugiwaka et al. 1999). According to the structure of the natural redd, we constructed two artificial redds in each tail of the pools, with one redd at a near-bank margin and another at the centre of the stream flow on October 1-2 (Fig. 3). Each redd was $1.5 \mathrm{~m}$ long and $1 \mathrm{~m}$ wide. Three vibert boxes (Whitlock vibert box; Whitlock 1977), each containing 400 eyed eggs, were buried in each redd; the eggs were placed $15 \mathrm{~cm}$ below the bed surface.

The hydrochemical variables on redd environment were measured immediately after installing the vibert boxes (October 3) and before collecting them (October 20-22). Although a considerable rainfall (45 mm/day) precipitated on October 11 (Fig. 2), the measurements were conducted under steady low-flow conditions to avoid flooding influences. To evaluate the fine sediment accumulation for the experiment period, the riverbed materials were sampled on each redd surface on October 20-22.

\section{Permeability test}

To obtain the permeability coefficient in the redds, a field permeability measurement using the packer test, an in-situ single well permeability test (Hvorslev 1951), was conducted at points near the vibert box (Fig. 3, see Yamada et al. (2005) for detailed information). This test was conducted by applying the same techniques as those used for that study. The permeability coefficient $(k)$ was then calculated from the following equation under Darcy flow conditions:

$$
k=\frac{Q_{p}}{2 \pi h l} \sinh ^{-1}\left(\frac{l}{2 r_{w}}\right),
$$


1 where $Q_{p}$ is the discharge pumped out of the well $\left(\mathrm{cm}^{3} / \mathrm{s}\right), l$ is the strainer's sectional length $(\mathrm{cm})$,

$2 h$ is the difference between the water heads $(\mathrm{cm})$, and $r_{w}$ is the standpipe's inner radius $(\mathrm{cm})$.

A standpipe made of a $4.6 \mathrm{~cm}$ diameter steel $(100 \mathrm{~cm}$ long $)$ with a strainer $(0.5 \mathrm{~mm}$

\section{Hydraulic variables of surface water and water quality}

Surface water velocity and depth were measured above the redds with a portable current meter (Model 3631; Yokogawa Electric Corp., Tokyo, Japan) at $60 \%$ of the water depth. Two types of water surface gradients were measured for each redd; the gradient between a pit and its tailspill (hereinafter designated as "the gradient of the tail"), and the other between a pool head to the next pool (hereinafter designated as "the gradient of the reach"), using a tilting level.

To investigate water quality in the redds, water samples were collected on two sampling occasions (Oct. 3, and Oct. 20-22). At each sampling location, a standpipe was installed immediately before sampling and fresh water was extracted using a hand pump (Hand vacuum pump; Nalge Nunc International) after the water remaining in the pipe was first removed. The sampling method followed the same procedure employed by Olsen and Townsend (2003) and Greig et al. (2005). The dissolved oxygen concentration (intragravel DO), pH (intragravel $\mathrm{pH}$ ), and water temperature (intragravel temp.) were measured using a DO meter (DO-14P, DKK-TOA Corp., Tokyo, Japan) that had been calibrated against the Winkler test, and a pH meter (HM-14P; DKK-TOA Corp., Tokyo, Japan). The surface-water quality parameters 
1 were measured above the bed surface where the vibert box was buried. Water quality was

2 allowed to vary with the diurnal temperature cycle. To eliminate the diel variation, water quality

3 data were sampled almost simultaneously on each survey day. To check chronological changes

4 of the water temperature in the redds and the cumulative temperature, intragravel water

5 temperature (IWTL) was monitored $15 \mathrm{~cm}$ below the bed surface at the centre of the tail sites

6 using data loggers (StowAway Tidbit Temp Logger; Onset Computer Corp., MA, USA) during

7 the experimental period (Fig. 3). Similarly, the surface water temperature was monitored using

8 the data logger at thalweg on St. 1.

\section{Bed material sampling and grain size analysis}

When the vibert boxes were dug out, the upper $15 \mathrm{~cm}$ of bed material was collected from each vibert box using a Surber sampler ( $25 \mathrm{~cm}$ quadrat, $0.25-\mathrm{mm}$ mesh size). Thereafter, we conducted particle size analysis in the laboratory using classified weight percentage (WP) and cumulative weight percentage. The bed materials were sorted using sieves with mesh sizes of $63 \mathrm{~mm}, 31.5 \mathrm{~mm}, 16 \mathrm{~mm}, 9.5 \mathrm{~mm}, 4 \mathrm{~mm}, 2 \mathrm{~mm}, 1 \mathrm{~mm}, 0.425 \mathrm{~mm}$, and $0.25 \mathrm{~mm}$. The classified weight percentage consisted of WP $31.5-63 \mathrm{~mm}$, WP 16-31.5 mm, WP 9.5-16 mm, WP 4-9.5 mm, WP 2-4 mm, WP 1-2 mm, WP $0.425-1 \mathrm{~mm}$, and WP $0.25-0.425 \mathrm{~mm}$, and the cumulative weight percentage was categorized as Fines $<4 \mathrm{~mm}$, Fines $<2 \mathrm{~mm}$, and Fines $<1$ $\mathrm{mm}$.

\section{Data analyses}

The embryos collected from the vibert boxes were examined to identify dead embryos and living alevin. The rate of embryo survival was calculated for each vibert box as follows.

$$
\text { Survival rate }(\%)=\frac{\text { Number of living alevins }}{\text { Total (dead embryo and living alevins) }} \times 100
$$
water quality variables (DO, $\mathrm{pH}$, water temperature) were calculated as follows. 

reflects the hydraulic gradient because the difference in velocity heads between two points (pit and tailspill) was extremely small. The rate of flow over the embryos, the intragravel flow rate, $Q\left(\mathrm{~cm}^{3} / \mathrm{s}\right)$, can be estimated as follows using Darcy's law:

$$
Q=k i A,
$$

7 where $k$ is the permeability coefficient $(\mathrm{cm} / \mathrm{s}), i$ is a hydraulic gradient (1), and $A$ is the crosssectional area containing the embryos in a vibert box $\left(\mathrm{cm}^{2}\right)$, defined as a product of the width and height of the box $(13 \mathrm{~cm} \times 2 \mathrm{~cm})$. Furthermore, the flux of intragravel dissolved oxygen, the DO flux (mg/hr), reaching the embryos can be estimated by multiplying the intragravel flow rate $(Q)$ and intragravel $\mathrm{DO}$ concentration $(\mathrm{mg} / \mathrm{L})$.

The groundwater - surface water interactions (extent of groundwater upwelling) and hyporheic water qualities vary with discharge fluctuations of the surface flow (Malcolm et al. 2003b; Malcolm et al. 2004); egg survival is mainly controlled by conditions existing during a low stream flow (Soulsby et al. 2001). Consequently, physicochemical data (e.g., water quality, water temperature, and permeability) obtained immediately before collecting the vibert boxes were used to reflect the representative data under a steady low-flow condition continuing for five days (Fig. 2). Regarding the intragravel water temperature, manually collected data were used for this analysis. Pearson's correlation coefficient was used to evaluate the relations among all variables. Stepwise multiple linear regression analysis was conducted to determine the most influential variables for embryo survival. To avoid multicollinearity, those independent variables that were significantly correlated mutually $(P<0.05)$ and which showed weak association with survival rate were eliminated. To improve normality and equity of variance, the survival rate was transformed to $x^{1 / 2}$, and the permeability coefficient, the DO flux, the classified weight percentage (WP) and cumulative weight percentage were transformed to $\log (x+1)$. These statistical analyses were conducted using software (SPSS for Windows ver.10.1.3 J; SPSS Japan 
2

\section{Results}

Unfortunately, the vibert boxes at sites 4 (centre and bank), 7 (bank), and 8 (bank) were washed away by flooding on October 11 (Fig. 2). For that reason, data at these sites were missing for additional analyses.

Differences in physical parameters at different sites were not large (Table 1). The surface water velocity and water depth respectively varied within $23-48 \mathrm{~cm} / \mathrm{s}$ and from $17-26$ $\mathrm{cm} / \mathrm{s}$. The velocity at St. 2 was slightly lower than at other sites. When collecting the vibert boxes, we observed fine sediment accumulation in the interstitial spaces of the gravel bed of 3-6 $\mathrm{cm}$ in diameter. The mean grain size, survival rate, permeability, and intragravel flow rate appear to decline in the sites downstream from the landslide (from St. 4 to St. 8, Appendix I). Moreover, these variables tended to become lower in the near-bank sites than in the centre of the pool tail.

Although IWTLs showed daily fluctuations synchronizing with surface water temperature, the daily lowest temperature tended to be higher than that of the surface water (Fig. 4(a)). These daily fluctuations were observed at each site during the water sampling period (Fig. 4(b)). The daily variation was slightly larger at downstream sites than at upstream sites.

\section{Relation between fine sediment deposition and environmental variables}

Correlation analyses showed a significant relation between permeability and some other physical variables (Table 2). The permeability coefficient was positively correlated with WP 16-31.5 mm and water depth, and negatively correlated with WP 2-4 mm, WP 1-2 mm, WP $0.425-1 \mathrm{~mm}$, Fines $<4 \mathrm{~mm}$, Fines $<2 \mathrm{~mm}$ and Fines $<1 \mathrm{~mm}$ (Table 2). Furthermore, the analyses of ratios of water quality and physical variables showed that the DO ratio was significantly negatively correlated with the permeability coefficient, WP $0.25-0.425 \mathrm{~mm}$, water depth, and the gradient of the reach (Table 2). The significant influences of water depth existed 
1 also on the DO ratio and permeability coefficient. Therefore, to remove the effect of water depth

2 on the correlation analyses, a partial correlation analysis was conducted using the water depth as

3 a control variable. No significant correlation between permeability coefficient and the DO ratio was found $\left(r_{p}=-0.32, P=0.064\right.$, d.f. $\left.=33\right)$. All DO ratios were lower than 1 (Fig. 5), suggesting that the intragravel DO concentration was always lower than surface water DO concentration. The $\mathrm{pH}$ ratio increased significantly with increasing permeability coefficient (Table 2, Fig. 5). Although the temperature ratio was not correlated with the permeability coefficient (Table 2), the variation of the temperature ratio tends to decrease concomitantly with increasing permeability, reaching almost 1.0 (Fig. 5).

Although the intragravel DO concentration was significantly negatively correlated with WP $0.25-0.425 \mathrm{~mm}$, the former was not significantly correlated with permeability (Table 3). In particular, the intragravel DO was strongly positively correlated with surface water DO, indicating that the intragravel DO concentration depends strongly on the surface water concentration.

\section{Relation between survival of embryos and environmental variables}

The correlation analysis between the survival rate and all physical and water quality variables showed that the survival rate was significantly correlated with all weight percentages (WP) except for WP 63-128 mm and WP 4-9.5 mm (Table 3). All variables for the cumulative percentage less than $4 \mathrm{~mm}$ showed negative associations with the survival rate. In particular, the survival rate decreased exponentially with increasing Fines $<2 \mathrm{~mm}$ and Fines $<1 \mathrm{~mm}$ (Figs. 6(a) and 6(b)); however, Fines $<2 \mathrm{~mm}$ is the much stronger predictor. The survival rate decreased rapidly when Fines $<2 \mathrm{~mm}$ exceeded 20\%; most embryos died when it exceeded 60\% (Fig. 6(a)).

The survival rate was correlated significantly with the permeability coefficient, surface water DO, intragravel temperature, surface water temperature, DO flux, and intragravel flow rate (Table 3). The survival rate decreased concomitantly with decreasing permeability, 
1 surface water DO concentration, DO flux and intragravel flow rate, being best explained by the

2 intragravel flow rate (Table 3). In addition, some observations revealed an extremely low 3 embryo survival rate when the permeability coefficient was less than $1 \mathrm{~cm} / \mathrm{s}$ and the DO flux 4 was less than $1 \mathrm{mg} / \mathrm{hr}$ (Figs. 6(c) and 6(d)).

To determine the best combination of independent variables to explain the survival rate, stepwise linear regression analysis was used. The grain size data were not used for this analysis because the permeability coefficient was strongly correlated with the composition of the bed material. The result showed that the survival rate was best explained by the combination of the permeability coefficient, intragravel DO, and the tail gradient (Table 4). The survival rate increased concomitantly with increasing permeability coefficient, intragravel DO concentration, and tail gradient. The regression coefficient of the permeability coefficient was the highest among these variables.

\section{Discussion}

\section{Effects of fine sediment on the redd environment}

16

The accumulation of fine sediment causes a decrease in intragravel flow rate (or velocity) with decreasing permeability of the riverbed because of clogging of gravel bed pores. Previous studies indicated that the permeability coefficient is inversely correlated with a cumulative weight percentage less than $0.84 \mathrm{~mm}$ (McNeil and Ahnell 1964) and the weight percentage of 0.125-1.0 mm (Murakami et al. 2001). In our study, a strong inverse correlation was found with the cumulative weight percentage less than $4 \mathrm{~mm}$ (Fines $<4 \mathrm{~mm}$ ). The differences in specific grain size that affect the permeability coefficient between previous studies and the present study suggest that permeability might depend not on a specific grain size but instead on the grain size distribution.

Surface water enters a redd at the pit by down-welling, and is discharged at the tailspill (Fig. 3) by up-welling (Vaux 1962; Cooper 1965). Generally, the discharges (intragravel flow rates) depend on the hydraulic gradient and permeability in a riverbed. Although we did 
1 not measure the hydraulic gradient directly, our stepwise regression analyses showed that the

2 gradient of the tail is an independent variable that is sufficiently strong to explain the survival

3 rate of embryos. The hydraulic gradient in a redd can be determined by the vertical position

4 (relative elevation) of the tailspill (Bjornn and Reiser 1991). Thereby the water surface gradient

5 (the gradient of tail) and the intragravel flow rate (or velocity) depend on local conditions

6 surrounding redd, as characterized by the water surface gradient on the redd and by the

7 permeability related to the amount of accumulated fine sediment.

The daily temperature variation at downstream sites was slightly greater than that at upstream sites, suggesting that the subsurface water temperature was partially regulated by surface water temperature warmed by insolation (Sugimoto et al. 1997), not by sediment accumulation. We considered that our water quality data represented normal values because the water temperature exhibited an ordinary pattern of daily fluctuation that was synchronized with surface water temperatures.

The $\mathrm{pH}$ ratio decreased concomitantly with the decreasing permeability coefficient, which is attributable to retention of intragravel water in the impermeable redds, resulting in an increase in organic acids and carbon dioxide produced from the respiration of live embryos and the decomposition of dead ones. The temperature ratio variation decreased concomitantly with increasing permeability, which suggests that the surface water can infiltrate easily into the permeable bed (Yamada et al. 2008). In contrast, the ratios varied under a low permeable condition because the subsurface water temperature was mainly regulated by groundwater rather than by surface water, as described by Malcolm et al. (2003b). However, partial correlation analysis revealed no significant relation between permeability and the DO ratio, suggesting that intragravel DO concentration was not affected directly by permeability, which varied with the fine sediment accumulation.

In general, the intragravel DO concentration is controllable by water temperature, interchange between surface and intragravel water, apparent velocity, permeability, and decomposition of organic matter in the redd (Bjornn and Reiser 1991). Furthermore, intragravel 
1 DO concentrations were affected by the extent of groundwater upwelling corresponding to

2 discharge fluctuation of surface water (Malcolm et al. 2003b). These indicated that limiting

3 factors for the intragravel DO concentration are complex locally and temporally. In particular,

4 many reports have described that intragravel DO concentration has a negative relation with

5 permeability and the percentage of fine sediment in substrates (Tagart 1976, 1984; Reiser and

6 White 1981) because interchange between surface and intragravel water is prevented by low

7 permeability (Tagart 1976, 1984). The intragravel DO concentration is high in highly permeable

8 riverbeds (Wells and McNeil 1970), although it is low in a riverbed covered by silt and such

9 materials of low permeability (Wickett 1954; Greig et al. 2005). In contrast, the intragravel DO

10 concentration is weakly correlated with the amount of accumulated fine sediment (Koski 1966).

11 Furthermore, the intragravel DO concentration depends on DO levels in the surface water; but is

12 consistently a little lower than that in surface water (Vining et al. 1985; Yamada et al. 2008).

13 These contrasting results are attributable to riverbed conditions. The former studies were of silty

14 riverbeds, where the permeability was extremely low, whereas the latter was on a sandy riverbed.

15 The bed situation in the present study resembled that of the latter cases. Consequently, 16 interchange of DO between intragravel and surface water was not directly affected by

17 permeability or the accumulated fine sediment; rather these influenced the intragravel flow rate, which in turn affected the DO flux supplied to embryos.

\section{Effects of fine sediment on embryos survival}

Previous reports have described that the survival rate and growth rate of embryos decrease concomitantly with increasing cumulative weight percentage to $6.4 \mathrm{~mm}$ (Bjornn 1968), $4.6 \mathrm{~mm}$ (Platts et al. 1979), $3.3 \mathrm{~mm}$ (Koski 1966), $2 \mathrm{~mm}$ (Hausle and Coble 1976), $0.85 \mathrm{~mm}$ (Koski 1966; Cederholm et al. 1981) and 0.84 mm (McNeil and Ahnell 1964; Tagart 1976). Koski (1966) and Cederholm et al. (1981) reported that the survival rate of coho salmon $(O$. kisutch) embryos decreased to $10-45 \%$ when the cumulative weight percentage to $0.85 \mathrm{~mm}$ exceeded $20 \%$ in their field studies. In our study, the survival rate of masu salmon embryo 
1 decreased to $20 \%$ when the cumulative weight percentage to $1.0 \mathrm{~mm}$ (Fines $<1 \mathrm{~mm}$ ) and 2.0

$2 \mathrm{~mm}($ Fines $<2 \mathrm{~mm}$ ) respectively exceeded $15 \%$ and $40 \%$ (Figs. 6(a) and $6(\mathrm{~b})$ ).

According to past studies that examined hydraulic parameters with respect to fine

sediment accumulation, embryo survival decreased concomitantly with decreasing permeability and apparent velocity in the redd for pink salmon (O. gorbuscha) (Wickett 1958), chinook salmon (O. tshawytscha) (Gangmark and Bakkala 1960), rainbow trout (O. mykiss) (Coble 1961), coho salmon (O. kisutch), steelhead trout (Phillips and Campbell 1961), and sockeye salmon (O. nerka) (Cooper 1965), which agrees with our results. The correlation analyses further revealed that the intragravel flow rate was a stronger explanatory variable for embryo survival than permeability, as supported by its larger correlation coefficient (Table 3).

Many researchers have confirmed that survival rates of salmonid embryos were affected by the intragravel DO concentration in the redd (e.g. Coble 1961; Phillips and Campbell 1961; Sowden and Power 1985; Rubin and Glimsater 1996; Malcolm et al. 2003b), but the critical DO concentration level was inconsistent. These differences might have originated from methods applied, salmonid species, water temperature, and reductions in DO associated with the embryos' respiration (Malcolm et al. 2004). In fact, embryo survival is controlled by the DO supply to meet consumption by embryos (Wickett 1954). Supporting this, our result indicates that the survival rate of masu salmon was positively correlated with the DO flux. Although results of correlation analyses show that the influence of intragravel DO concentration on the survival rate was insignificant, the former was selected as the independent variable with the permeability coefficient based on results of regression analysis. Results suggest that the combination reflects the DO flux.

The amount of oxygen consumed by one egg of masu salmon embryos is expected to be $0.001 \mathrm{mg} / \mathrm{h}$ at about $11^{\circ} \mathrm{C}$ of water temperature (Kawajiri 1925). Therefore, oxygen consumption by 400 embryos will reach $0.4 \mathrm{mg} / \mathrm{hr}$. The survival rate declined to an extremely low level when the DO flux became less than $1 \mathrm{mg} / \mathrm{h}$ (Fig. 6(d)), which is reasonably consistent with the oxygen consumption estimated above. Consequently, the negative relation between the 
1 survival rate and DO flux in our result is explainable by suffocation because of an insufficient

2 DO supply. In addition, the DO flux, required for successful incubation, increased with

3 advancement of the embryo growth-stage and increasing water temperature (Wickett 1954;

4 Bjornn and Reiser 1991). Therefore, in some cases, a high survival rate might occur even at a

5 low level of DO flux, depending on the growth stage and water temperature.

6

In conclusion, fine sediment accumulation in the riverbed enhances mortality through suffocation because the reduced intragravel flow and permeability limit the DO flux that is normally available to the embryos. Given the close association between DO concentration in the riverbed and surface water, we expect that suffocation might become more serious under conditions combining low DO concentration in the surface water and large amounts of fine sediment in the riverbed.

Although this study did not examine the effects of large-scale valley/channel morphology on exchanges between surface and subsurface flow and on quality of the spawning habitat (e.g. Wondzell and Swanson 1996; Boulton et al. 1998; Baxter and Hauer 2000), embryo survival was generally explained by changes in the riverbed permeability, DO flux and hydraulic gradient in a redd associated with fine sediment deposition on a local scale (Malcolm et al. 2003a), as indicated by the fact that the water surface gradient of the tail was a significant variable in supplying DO to the redds.

\section{Acknowledgments}

We would like to express our gratitude to Dr Miyuki Nakajima and the staff of the Hokkaido Fish Hatchery, and Dr Akiko Nagasaka in the Hokkaido Forestry Research Institute, and Professor Seiji Yanai, Hokkaido Institute of Technology for providing embryos, data, and other generous cooperation. We also thank Professors Tohru Araya, Koji Maekawa, Takashi Yamada, and Shun-ichi Kikuchi, Faculty of Agriculture, Hokkaido University, and Professors Makoto Nishigaki and Mitsuru Komatsu, Department of Environmental and Civil Engineering, Okayama University, for useful advice. We are also grateful to Mrs. Tomoko Yamada, Ms. 
1 Marie Murakami, and students in the Department of Forest Science, Hokkaido University, for

2 assistance. This research was supported in part by Grants in Aid for Scientific Research from the

3 Ministry of Education, Culture, Sports, Science and Technology (Nos. 13460061, 14380274,

4 14506039, and 17780242), and by funds from the Technology Research Centre for Riverfront

5 Development; the River Environment Fund (REF) of the Foundation of River and Watershed

6 Environment Management (FOREM); the workshop fund of Japan Society of Erosion Control

7 Engineering. 
2 Allan JD, Erickson DL, Fay J (1997) The influence of catchment land use on stream integrity across multiple spatial scales. Freshwater Biology 37: 149-161

4 Barton BA (1977) Short-term effects of highway construction on the limnology of a small stream in southern Ontario. Freshwater Biology 7: 99-108

Baxter CV. Hauer FR (2000) Geomorphology, hyporheic exchange, and selection of spawning habitat by bull trout (Salvelinus confluentus). Canadian Journal of Fisheries and Aquatic

Berkman HE, Rabeni CF (1987) Effect of siltation on stream fish communities. Environmental Biology of Fishes 18: 285-294

Bjornn TC (1968) Survival and emergence of trout and salmon fry in various gravel-sand mixtures. Logging and Salmon: Proceedings of a Forum, American Institute of Fishery Research Biologists. Alaska: 80-88

Bjornn TC, Reiser DW (1991) Habitat requirements of salmonids in streams. In Influence of Forest and Rangeland Management on Salmonid Fishes and Their Habitats, Meehan WR (ed.). American Fisheries Society Special Publication 19: 83-138

Boulton AJ, Findlay S, Marmonier P, Stanley EH, Valett HM (1998) The functional significance of the hyporheic zone in streams and rivers. Annual Review of Ecology and Systematics 29: $59-81$

Cederholm CJ, Reid LM, Salo EO (1981) Cumulative effects of logging road sediment on salmonid populations in Clearwater River, Jefferson County, Washington. Proceedings of a conference on salmon spawning gravel: a renewable resource in the Pacific Northwest. Washington State University, Water Research Centre Report 39, Pullman: 38-74

Chapman DW (1988) Critical review of variables used to define effect of fines in redds of large salmonids. Transactions of the American Fisheries Society 117: 1-21

Cline LD, Short RA, Ward JV (1982) The influence of highway construction on the macroinvertebrates and epilithic algae of a high mountain stream. Hydrobiologia 96: 149- 
2 Coble DW (1961) Influence of water exchange and dissolved oxygen in redd on survival of steelhead trout embryos. Transactions of the American Fisheries Society 90: 469-474

4 Cooper AC (1965) The effect of transported stream sediments on survival of sockeye and pink salmon eggs and alevin. International Pacific Salmon Fisheries Commission Bulletin 18

Extence CA (1978) The effects of motorway construction on an urban stream. Environmental Pollution 17: 245-252

8 Gangmark HA, Bakkala RG (1960) A comparative study of unstable and stable (artificial channel) spawning streams for incubating King salmon at Mill Creek. California Fish and Game 46: 151-164

Greig SM, Sear DA, Carling PA (2005) The impact of fine sediment accumulation on the survival of incubating salmon progeny: Implications for sediment management. Science of the Total Environment 344: 241-258

Greig SM, Sear DA, Carling PA (2007) A review of factors influencing the availability of dissolved oxygen to incubating salmonid embryos. Hydrological Processes 21: 323-334 DOI: $10.1002 /$ hyp.6188

Hausle DA, Coble DW (1976) Influence of sand in redds on survival and emergence of brook trout (Salvelinus fontinalis). Transactions of the American Fisheries Society 105: 57-63

Hellawell JM (1986) Biological Indicators of Freshwater Pollution and Environmental Management. Elsevier Applied Science: Barking

Hokkaido Forestry Research Institute, Hokkaido Fish Hatchery, Hokkaido Central Agricultural Experiment Station (1998) Study of riparian environment restoration in rural areas, Bulletin of Hokkaido Forestry Research Institute, Hokkaido Fish Hatchery and Hokkaido Central Agricultural Experiment Station: 1-76 (in Japanese)

Hokkaido Forestry Research Institute, Hokkaido Fish Hatchery, Hokkaido Central Agricultural Experiment Station (1999) Study of riparian environment restoration in rural areas, Bulletin of Hokkaido Forestry Research Institute, Hokkaido Fish Hatchery and Hokkaido Central 
Agricultural Experiment Station: 1-109 (in Japanese)

Hokkaido Forestry Research Institute, Hokkaido Fish Hatchery, Hokkaido Central Agricultural Experiment Station (2000) Study of riparian environment restoration in rural areas, Bulletin of Hokkaido Forestry Research Institute, Hokkaido Fish Hatchery and Hokkaido Central Agricultural Experiment Station: 1-99 (in Japanese)

Hvorslev MJ (1951) Time lag and soil permeability in ground-water observations. U.S. Corps of Eng. Waterways Exp. Sta. Vicksburg. Miss. Bull. 36: 50

Japan Weather Association (2000) AMeDAS annual report (CD-ROM), Japan Meteorological Business Support Centre, Tokyo

Japan Weather Association (2001) Annual report of precipitation, water level and discharge (uryo suii ryuuryo nenpyou), Doboku Society of Hokkaido, Sapporo

Kato F (1991) Life histories of masu and amago salmon (Oncorhynchus masou and Oncorhynchus rhodurus). In Pacific Salmon Life Histories, Groot C and Margolis L (eds.). UBC Press, Vancouver. 447-520

Kawajiri M (1925) On the oxygen consumption during development of the eggs and fly of the masu salmon (O. masou land-locked). Japan Imp. Fish. 21(2): 18-20

Koski KV (1966) The survival of coho salmon (Oncorhynchus kisutch) from egg deposition to emergence in three Oregon coastal streams. Masters thesis. Oregon State University, Corvallis

Malcolm IA, Soulsby C, Youngson A, Petry J (2003a) Heterogeneity in ground water - surface water interactions in the hyporheic zone of a salmonid spawning stream: towards integrating hydrometric and tracer approaches. Hydrological Processes 17: 601-617

Malcolm IA, Youngson A, Soulsby C (2003b) Survival of salmonid eggs in gravel bed streams: effects of groundwater-surface water interactions. River Research and Applications 19(4): $303-316$

Malcolm IA, Soulsby C, Youngson AF, Hannah DM, McLaren IS and Thorne A (2004) Hydrological influences on hyporheic water quality: implications for salmon egg survival. 
Hydrological Processes 18: 1543-1560. DOI: 10.1002/hyp.1405

Mayama H (1992) Studies of the freshwater life and propagation technology of masu salmon (Oncorhynchus masou Brevoot). Scientific Reports of the Hokkaido Salmon Hatchery 46: 1-156 (in Japanese with English abstract)

McNeil WJ, Ahnell WH (1964) Success of pink salmon spawning relative size of spawning bed materials. U.S. Fish and Wildlife Service Spatial Scientific Report Fisheries, 469

Murakami M, Yamada H, Nakamura F (2001) Hydraulic conductivity of substrate and openwork gravel rate associated with fine sediment deposition in mountain streams, southern Hokkaido. Ecology and Civil Engineering 4(2): 109-120 (in Japanese with English abstract)

Nagasaka A, Nakajima M, Yanai S, Nagasaka Y (2000) Influences of substrate composition on stream habitat and macroinvertebrate communities: a comparative experiment in a forested and an agricultural catchment. Ecology and Civil Engineering 3: 234-254 (in Japanese with English abstract)

Nakamura F, Sudo T, Kameyama S, Jitsu M (1997) Influences of channelization on discharge of suspended sediment and wetland vegetation in Kushiro Marsh, northern Japan. Geomorphology 18: 279-289

Nakamura F, Kameyama S, Mizugaki S (2004) Rapid shrinkage of Kushiro Mire, the largest mire in Japan, due to increased sedimentation associated with land-use development in the catchment. Catena 55: 213-229

Nakamura F, Yamada H (2005) Effects of pasture development on ecological functions of riparian forests in Hokkaido in northern Japan. Ecological Engineering 24: 539-550

Nakamura F, Kawaguchi Y, Nakano D, Yamada H (2008) Ecological responses to anthropogenic alterations of gravel-bed rivers in Japan, from floodplain river segments to the microhabitat scale: a review. In Gravel-Bed Rivers VI: From Process Understanding to River Restoration, Habersack H, Pie' gay H, Rinaldi M (eds.). Elsevier: 501-523

Olsen DA, Townsend CR (2003) Hyporheic community composition in a gravel-bed stream: 
influence of vertical hydrological exchange, sediment structure and physicochemistry. Freshwater Biology 48; 1363-1378

Phillips RW, Campbell HJ (1961) The embryonic survival of coho salmon and steelhead trout as influenced by some environmental conditions in gravel beds. 14th Annual Report of the Pacific Marine Fisheries Commission. Portland, Oregon; 60-73

Platts WS, Shirazi MA, Lewis DH (1979) Sediment particle sizes used by salmon for spawning with methods for evaluation. U.S. Environmental Protection Agency EPA 600/3-79-043. Corvallis, Oregon

Platts WS, Torquemada RJ, McHenry ML, Graham CK (1989) Changes in salmon spawning and rearing habitat from increased delivery of fine sediment to the South Fork Salmon River, Idaho. Transactions of the American Fisheries Society 118: 274-283

Reiser DW, White RG (1981) Incubation of steelhead trout and spring Chinook salmon eggs in a moist environment. Progressive Fish-Culturist 43: 131-134

Rubin JF, Glimsater C (1996) Egg-to-fry survival of the sea trout in some streams of Gotland. Journal of Fish Biology 48: 585-606

Sato H, Yanai S, Nagasaka Y, Nagasaka A, Sato H (2002) Influence of land use on suspended sediment discharge from watersheds emptying into Funka Bay, southwestern Hokkaido, northern Japan. J. Japan Soc. Hydrol. \& Water Resour. 152: 117-127 (in Japanese with English abstract)

Soulsby C, Malcolm I, Youngson A (2001) Hydrochemistry of the hyporheic zone in salmon spawning gravels: a preliminary assessment in a small regulated stream. Regulated Rivers, Research and Management 17: 651-665

Sowden TK, Power G (1985) Prediction of rainbow trout embryo survival in relation to groundwater seepage and particle size of spawning substrates. Transactions of the American Fisheries Society 114: 804-812

Sugimoto, S., Nakamura, F. and Ito, A (1997) Heat budget and statistical analysis of the relationship between stream temperature and riparian forest in the Toikanbetsu Stream, 
northern Japan. Journal of Forest Research 2: 103-107

Sugiwaka K, Takeuchi K, Suzuki K, Nagata M, Miyamoto M, Kawamura H (1999) Distribution and structure of spawning redds of masu salmon in the Atsuta River. Sci. Rep. Hokkaido Fish Hatchery 53: 11-28 (in Japanese with English abstract)

Tagart JV (1976) The survival from egg deposition to emergence of coho salmon in the Clearwater River, Jefferson County, Washington. Master's thesis. Univ. of Washington. Seattle

Tagart JV (1984) Coho salmon survival from egg deposition to emergence. Proceedings of the Olympic Wild Fish Conference, Walton JM and Houston DB (eds). Peninsula College, Fisheries Technology Program, Port Angeles, Washington; 173-182

Tappel PD, Bjornn TC (1983) A new method of relating size of spawning gravel to salmonid embryo survival. North American Journal of Fisheries Management 3: 123-135

Vaux WG (1962) Interchange of stream and intergravel water in a salmon spawning riffle. U.S. Fish and Wildlife Service SSR

Vining TJ, Blakely S, Freeman GM (1985) An evaluation of the incubation life-phase of chum salmon in the middle Susitna River, Alaska. Alaska Department of Fish and Game Report 5. Anchorage

Watanabe K, Nakamura F, Kamura K, Yamada H, Watanabe Y, Tsuchiya S (2001) Influence of stream alteration on the abundance and distribution of benthic fish. Ecology and Civil Engineering 42(2): 133-146 (in Japanese with English abstract)

Waters TF (1995) Sediment in Streams - Sources, Biological Effects, and Control. American Fisheries Society Monograph, 7, Maryland

Wells RA, McNeil WJ (1970) Effect of quality of the spawning bed on the growth and development of pink salmon embryos and alevins. U.S. Fish and Wildlife Service Spatial Scientific Report Fisheries 616

Whitlock D (1977) The Whitlock Vibert Box Handbook, Federation of Fly Fisherman: West Yellowstone 
1 Wickett WP (1954) The oxygen supply to salmon eggs in spawning beds. Journal of the Fisheries Research Board of Canada 11: 933-953

Wickett WP (1958) Review of certain environmental factors affection the production of pink and chum salmon. Journal of the Fisheries Research Board of Canada 15: 1103-1126

Wondzell SM, Swanson FJ (1996) Seasonal and storm dynamics of the hyporheic zone of a 4thorder mountain stream. I: hydrologic processes. Journal of the North American Benthological Society 15: 3-19

Wood PJ, Armitage PD (1997) Biological effect of fine sediment in the lotic environment, Environmental Management 21(2): 203-217

Yamada H, Nakamura F (2002) Effect of fine sediment deposition and channel works on periphyton biomass in the Makomanai River, northern Japan. River Research and Applications 18: 481-493

Yamada H, Nakamura F, Watanabe Y, Murakami M, Nogami T (2005) Measuring hydraulic permeability in a streambed using the packer test. Hydrological Processes 19: 2507-2524

Yamada H, Kawaguchi Y, Edo K, Komiyama E (2008) Effects of fine sediment accumulation on the redd environment and the survival rate of eyed embryos of Sakhalin taimen (Hucho perryi) in mountain streams of northern Hokkaido. Ecol. Civil. Eng. 11(1): 29-40 (in Japanese with English abstract) 
2

3 Fig. 1. Location of the Nukibetsu River Basin (a), and the study site in the Oroennukibetsu

4 River (b). Solid circles with a number show the research sites (tail of pool).

5

6 Fig. 2. Study period and annual water discharge, air temperature, precipitation at the river mouth

7 of Nukibetsu R. in 1999 (Japan Weather Association 2000, 2001).

8

9 Fig. 3. Installation of artificial masu salmon redd and the packer test equipment in each site.

10

11 Fig. 4. Chronological variations of intragravel and surface water (SW) temperature at each centre site for study period (a) and for water sampling period (b) in 1999 (Air temperature and precipitation data, Japan Weather Association 2000, 2001).

15 Fig. 5. Relation between redd permeability and water quality ratios.

17 Fig. 6. Relation between survival rate of masu salmon embryo and cumulative weight percentage less than $2.0 \mathrm{~mm}$ (Fines $<2.0 \mathrm{~mm}$ ) (a) and $1.0 \mathrm{~mm}$ (Fines $<1.0 \mathrm{~mm}$ ) (b), permeability (c), DO flux (d). 
Table 1. Geomorphic and hydraulic description of tail and redd. "-" indicates no data.

\begin{tabular}{|c|c|c|c|c|c|c|c|}
\hline \multirow{2}{*}{ Site } & \multirow{2}{*}{ Position } & \multirow{2}{*}{ Tail length (m) } & \multicolumn{2}{|c|}{ Wetted width (m) } & \multirow{2}{*}{$\begin{array}{c}\text { Gradient of tail } \\
(\%)\end{array}$} & \multirow{2}{*}{$\begin{array}{c}\text { Surface water } \\
\text { velocity }(\mathrm{cm} / \mathrm{s})\end{array}$} & \multirow{2}{*}{ Water depth $(\mathrm{cm})$} \\
\hline & & & Mean & SE & & & \\
\hline \multirow{2}{*}{1} & Centre & \multirow{2}{*}{6.10} & \multirow{2}{*}{3.07} & \multirow{2}{*}{0.11} & 0.29 & 56.57 & 23.67 \\
\hline & Bank & & & & 0.76 & 59.94 & 14.00 \\
\hline \multirow{2}{*}{2} & Centre & \multirow{2}{*}{6.40} & \multirow{2}{*}{4.77} & \multirow{2}{*}{0.06} & 0.29 & 21.47 & 18.00 \\
\hline & Bank & & & & 0.18 & 27.11 & 32.00 \\
\hline \multirow{2}{*}{3} & Centre & \multirow{2}{*}{10.50} & \multirow{2}{*}{3.63} & \multirow{2}{*}{0.17} & 0.39 & 41.82 & 22.33 \\
\hline & Bank & & & & 0.25 & 38.85 & 18.33 \\
\hline \multirow{2}{*}{4} & Centre & \multirow{2}{*}{7.00} & \multirow{2}{*}{4.00} & \multirow{2}{*}{0.05} & 0.35 & 22.86 & 11.67 \\
\hline & Bank & & & & 0.28 & 20.69 & 14.67 \\
\hline \multirow{2}{*}{5} & Centre & \multirow{2}{*}{7.00} & \multirow{2}{*}{5.50} & \multirow{2}{*}{0.15} & -0.01 & 53.98 & 25.33 \\
\hline & Bank & & & & 0.09 & 34.25 & 22.67 \\
\hline \multirow{2}{*}{6} & Centre & \multirow{2}{*}{5.00} & \multirow{2}{*}{5.55} & \multirow{2}{*}{0.04} & 0.26 & 34.74 & 17.00 \\
\hline & Bank & & & & 0.08 & 31.76 & 18.33 \\
\hline \multirow{2}{*}{7} & Centre & \multirow{2}{*}{3.00} & \multirow{2}{*}{5.89} & \multirow{2}{*}{0.15} & -0.01 & 36.95 & 22.67 \\
\hline & Bank & & & & - & - & - \\
\hline \multirow{2}{*}{8} & Centre & 340 & 553 & 003 & 0.05 & 36.46 & 12.33 \\
\hline & Bank & 3.40 & 5.53 & 0.03 & 0.17 & 37.53 & 16.00 \\
\hline
\end{tabular}


Table 2. Correlation coefficients between variables. * and ** indicate significance levels at $P<0.05$ and $P<0.01$, respectively $(n=36)$. Variables with $\dagger$ were transformed to log $(\mathrm{x}+1)$.

\begin{tabular}{|c|c|c|c|c|}
\hline Variable & Permeability $^{\dagger}$ & DO ratio & $\mathrm{pH}$ ratio & Temp. ratio \\
\hline Permeability $^{\dagger}$ & & $-0.420 *$ & $0.379 *$ & 0.206 \\
\hline WP $63-128 \mathrm{~mm}^{\dagger}$ & -0.123 & 0.279 & -0.305 & 0.058 \\
\hline WP $31.5-63 \mathrm{~mm}^{\dagger}$ & 0.293 & -0.245 & 0.319 & 0.238 \\
\hline WP $16-31.5 \mathrm{~mm}^{\dagger}$ & $0.565 * *$ & 0.004 & 0.153 & $0.506 * *$ \\
\hline WP 9.5-16 $\mathrm{mm}^{\dagger}$ & 0.304 & 0.046 & 0.107 & 0.326 \\
\hline WP 4-9.5 $\mathrm{mm}^{\dagger}$ & -0.232 & 0.253 & -0.130 & -0.056 \\
\hline WP 2-4 $\mathrm{mm}^{\dagger}$ & $-0.413 *$ & 0.287 & -0.221 & -0.288 \\
\hline WP $1-2 \mathrm{~mm}^{\dagger}$ & $-0.453 * *$ & 0.226 & -0.149 & -0.234 \\
\hline WP $0.425-1 \mathrm{~mm}^{\dagger}$ & $-0.457 * *$ & 0.245 & -0.261 & -0.188 \\
\hline WP $0.25-0.425 \mathrm{~mm}^{\dagger}$ & -0.122 & $-0.413 *$ & 0.056 & -0.229 \\
\hline Fines $<4.0 \mathrm{~mm}^{\dagger}$ & $-0.478 * *$ & 0.236 & -0.203 & -0.290 \\
\hline Fines $<2.0 \mathrm{~mm}^{\dagger}$ & $-0.466 * *$ & 0.190 & -0.178 & -0.255 \\
\hline Fines $<1.0 \mathrm{~mm}^{\dagger}$ & $-0.431 * *$ & 0.094 & -0.224 & -0.245 \\
\hline Surface water velocity & 0.054 & -0.204 & 0.175 & $0.380 *$ \\
\hline Water depth & $0.418 *$ & $-0.364 *$ & 0.085 & -0.051 \\
\hline Gradient of reach & 0.209 & $-0.441 * *$ & 0.170 & 0.253 \\
\hline Gradient of tail & 0.058 & -0.318 & 0.293 & $0.335 *$ \\
\hline
\end{tabular}


Table 3. Correlation coefficients between variables. ${ }^{*}$ and $* *$ indicate significance levels at $P<$ 0.05 and $P<0.01$, respectively $(n=36)$. Variables with $\dagger$ and $\dagger \dagger$ were transformed to $\mathrm{x}^{1 / 2}$ and $\log$ $(\mathrm{x}+1)$, respectively.

\begin{tabular}{|c|c|c|c|c|c|c|c|c|}
\hline Variable & \multicolumn{2}{|c|}{ Survival rate ${ }^{\dagger}$} & \multicolumn{2}{|c|}{$\begin{array}{c}\text { Intragravel } \\
\text { DO }\end{array}$} & \multicolumn{2}{|c|}{$\begin{array}{c}\text { Intragravel } \\
\mathrm{pH}\end{array}$} & \multicolumn{2}{|c|}{$\begin{array}{c}\text { Intragravel } \\
\text { Temp. }\end{array}$} \\
\hline Permeability $^{\dagger \dagger}$ & 0.434 & *** & -0.190 & & 0.077 & & 0.005 & \\
\hline WP $63-128 \mathrm{~mm}^{\dagger \dagger}$ & 0.120 & & 0.495 & $* *$ & 0.230 & & -0.210 & \\
\hline WP $31.5-63 \mathrm{~mm}^{\dagger \dagger}$ & 0.617 & $* *$ & 0.095 & & -0.236 & & -0.230 & \\
\hline WP $16-31.5 \mathrm{~mm}^{\dagger \dagger}$ & 0.789 & $* *$ & 0.211 & & -0.108 & & -0.230 & \\
\hline WP 9.5-16 $\mathrm{mm}^{\dagger \dagger}$ & 0.677 & $* *$ & 0.257 & & -0.060 & & -0.291 & \\
\hline WP 4-9.5 $\mathrm{mm}^{\dagger \dagger}$ & 0.133 & & 0.146 & & -0.019 & & -0.141 & \\
\hline WP 2-4 $\mathrm{mm}^{\dagger \dagger}$ & -0.558 & $* *$ & -0.099 & & 0.105 & & 0.197 & \\
\hline WP $1-2 \mathrm{~mm}^{\dagger \dagger}$ & -0.698 & $* *$ & -0.115 & & 0.003 & & 0.114 & \\
\hline WP $0.425-1 \mathrm{~mm}^{\dagger \dagger}$ & -0.558 & $* *$ & 0.061 & & 0.027 & & 0.059 & \\
\hline WP $0.25-0.425 \mathrm{~mm}^{\dagger \dagger}$ & -0.471 & $* *$ & -0.444 & $* *$ & -0.017 & & 0.160 & \\
\hline Fines $<4.0 \mathrm{~mm}^{\dagger \dagger}$ & -0.679 & $* *$ & -0.115 & & 0.055 & & 0.161 & \\
\hline Fines $<2.0 \mathrm{~mm}^{\dagger \dagger}$ & -0.686 & $* *$ & -0.102 & & 0.024 & & 0.124 & \\
\hline Fines $<1.0 \mathrm{~mm}^{\dagger \dagger}$ & -0.591 & $* *$ & -0.069 & & 0.042 & & 0.115 & \\
\hline Surface water velocity & 0.208 & & -0.020 & & -0.469 & $* *$ & -0.544 & $* *$ \\
\hline Water depth & 0.100 & & -0.446 & $* *$ & 0.177 & & 0.379 & $*$ \\
\hline Gradient of reach & 0.304 & & -0.133 & & -0.434 & $* *$ & -0.499 & $* *$ \\
\hline Gradient of tail & 0.321 & & -0.068 & & -0.667 & $* *$ & -0.506 & $* *$ \\
\hline Intragravel DO concentration & 0.283 & & & & -0.116 & & -0.546 & $* *$ \\
\hline Surface water DO concentration & 0.355 & $*$ & 0.914 & $* *$ & -0.156 & & -0.621 & $* *$ \\
\hline Intragravel $\mathrm{pH}$ & -0.211 & & -0.116 & & & & 0.650 & $* *$ \\
\hline Surface water $\mathrm{pH}$ & -0.209 & & -0.034 & & 0.923 & $* *$ & 0.614 & $* *$ \\
\hline Intragravel Temp. & -0.347 & $*$ & -0.546 & $* *$ & 0.650 & $* *$ & & \\
\hline Surface water Temp. & -0.399 & $*$ & -0.542 & $* *$ & 0.666 & $* *$ & 0.992 & $* *$ \\
\hline DO flux ${ }^{\dagger \dagger}$ & 0.456 & $* *$ & -0.146 & & -0.319 & & -0.337 & $*$ \\
\hline Intragravel flow rate $e^{\dagger \dagger}$ & 0.549 & $* *$ & -0.190 & & -0.326 & & -0.294 & \\
\hline
\end{tabular}


Table 4. Results of stepwise linear regression analysis $(n=36)$.

\begin{tabular}{lcccc}
\hline \multicolumn{1}{c}{ Independent variables } & $\begin{array}{c}\text { Standard regression } \\
\text { coefficient }\end{array}$ & $R^{2}$ & $F$ & $P$ \\
\hline \hline Survival rate & 0.43 & 0.19 & 7.88 & 0.008 \\
Permeability & 0.51 & 0.33 & 8.00 & 0.001 \\
& 0.38 & & & \\
Permeability & 0.49 & 0.43 & 7.98 & $<0.001$ \\
Intragravel DO concentration & 0.40 & & & \\
Permeability & 0.32 & & & \\
Intragravel DO concentration & &
\end{tabular}




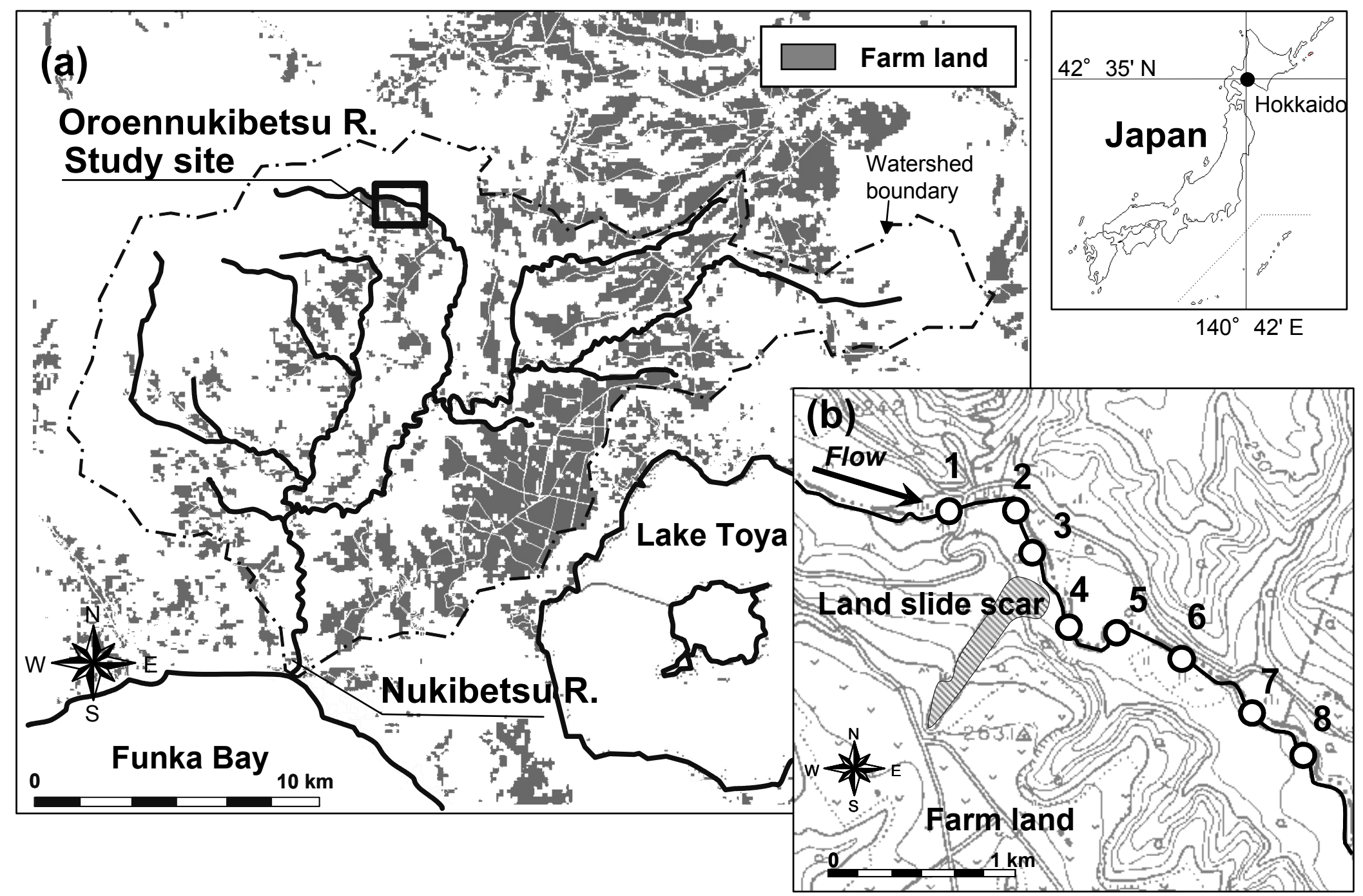

Fig. 1. Location of the Nukibetsu River Basin (a), and the study site in the Oroennukibetsu River (b). Solid circles with a number show the research sites (tail of pool). 


\section{Yamada \& Nakamura}

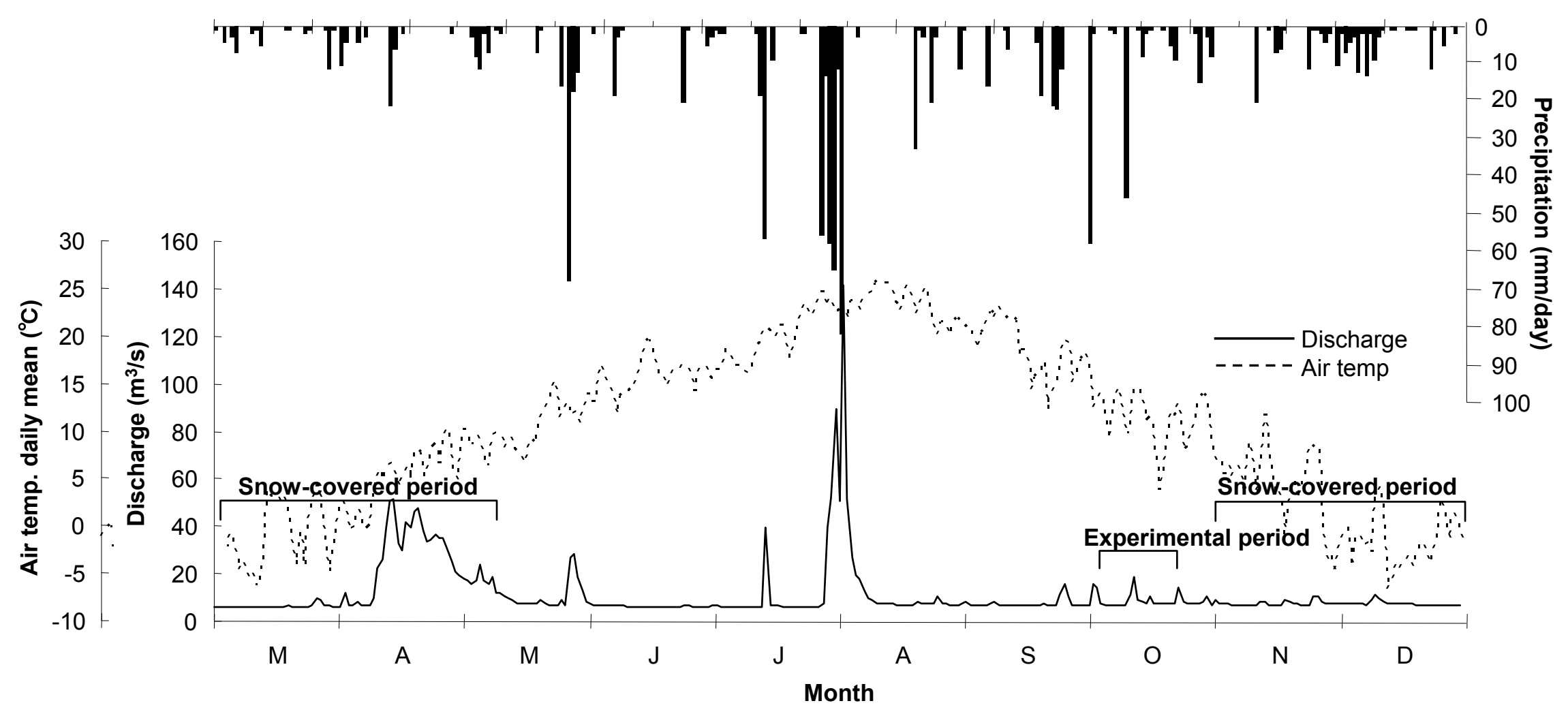

Fig. 2. Study period and annual water discharge, air temperature, precipitation at the river mouth of Nukibetsu R. in 1999 (Japan Weather Association 2000, 2001). 

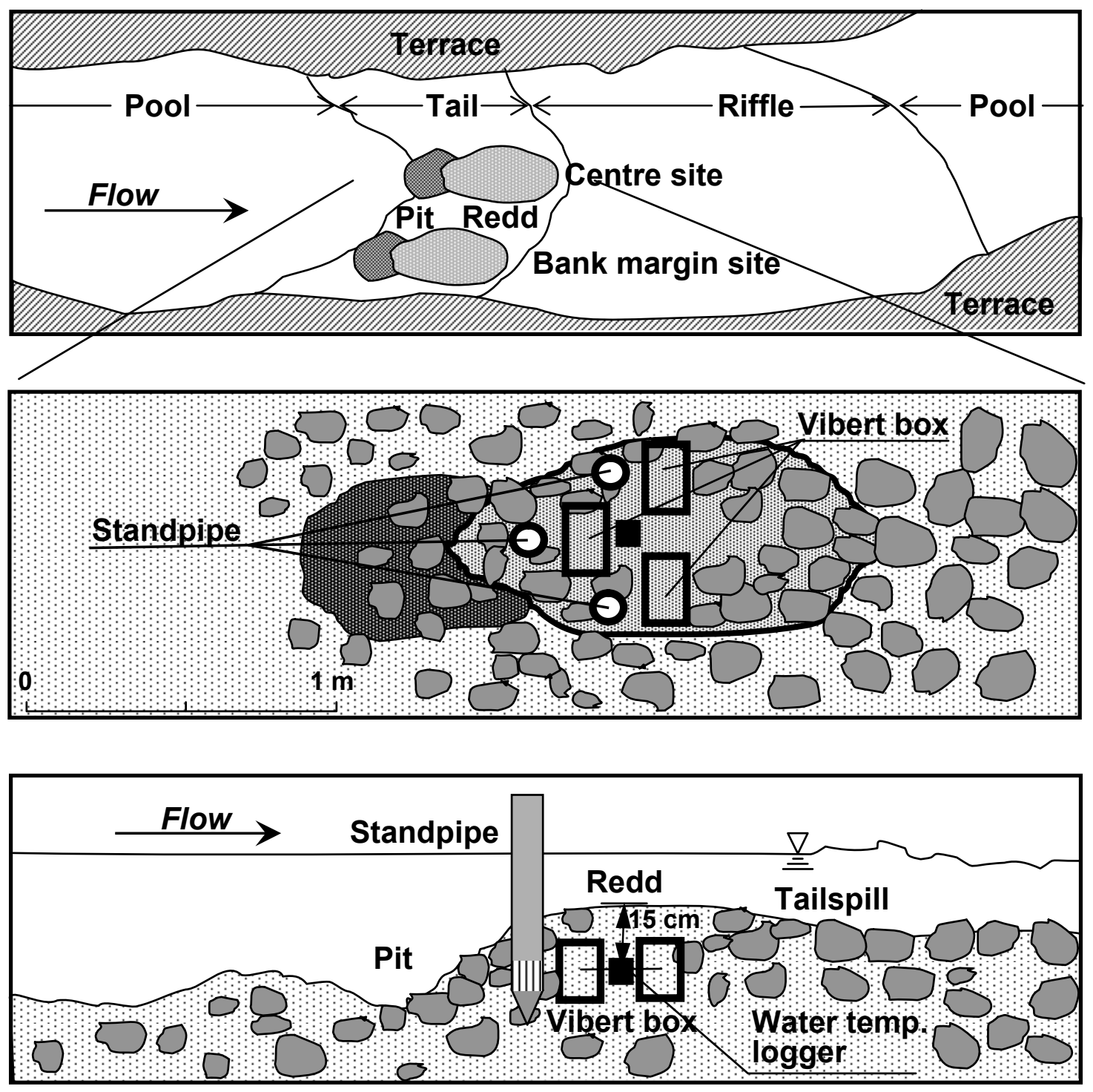

Fig. 3. Installation of artificial masu salmon redd and the packer test equipment in each site. 


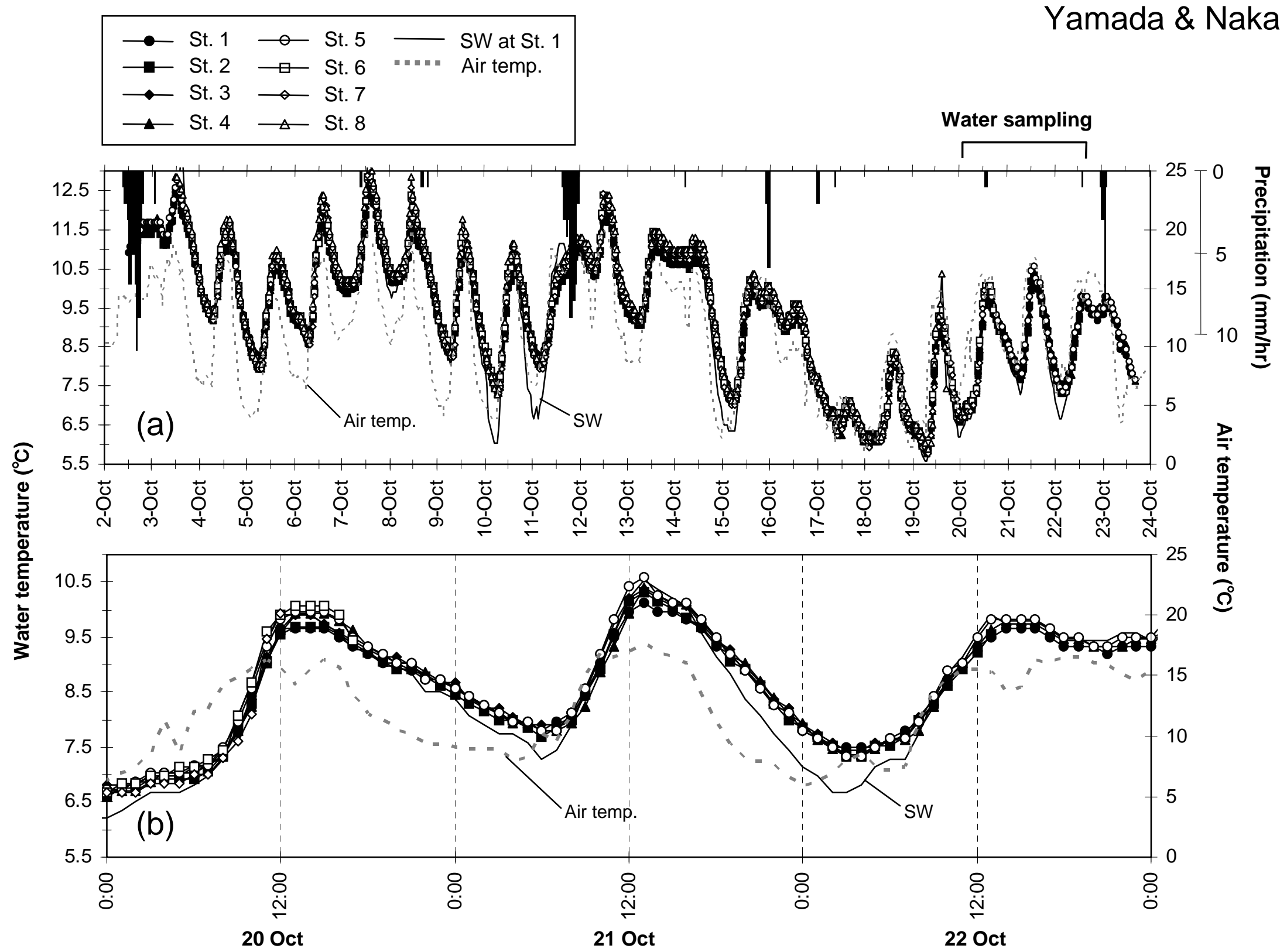

Fig. 4. Chronological variations of intragravel and surface water (SW) temperature at each centre site for study period (a) and for water sampling period (b) in 1999 (Air temperature and precipitation data, Japan Weather Association 2000, 2001). 


\section{Yamada \& Nakamura}
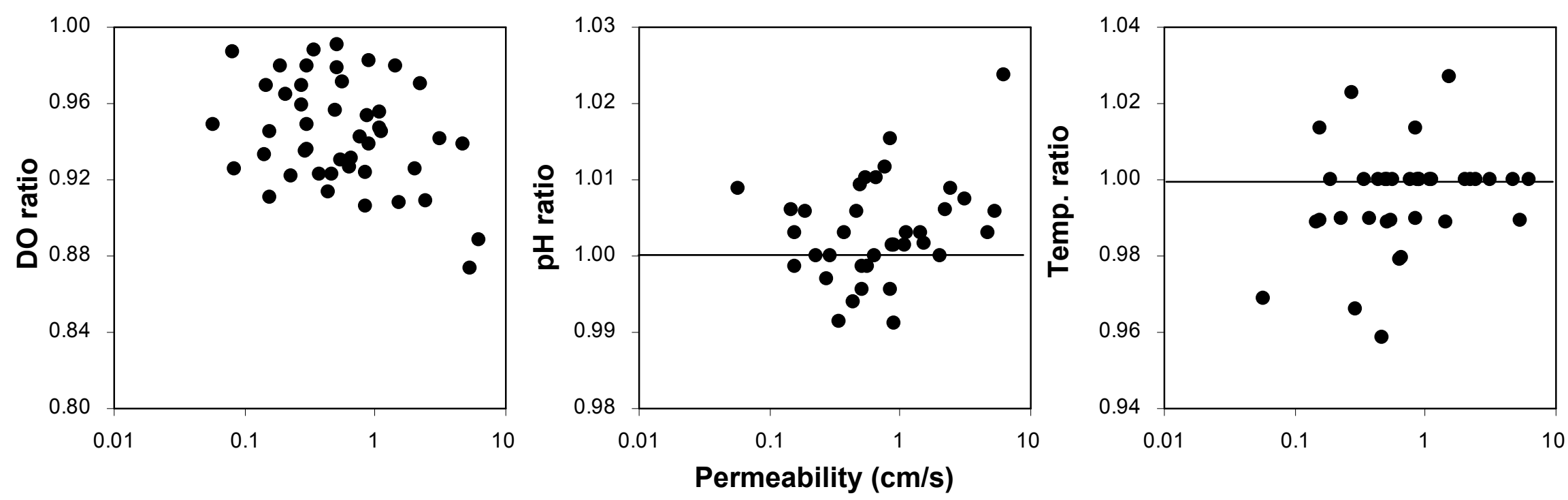

Fig. 5. Relation between redd permeability and water quality ratios. 
Yamada \& Nakamura
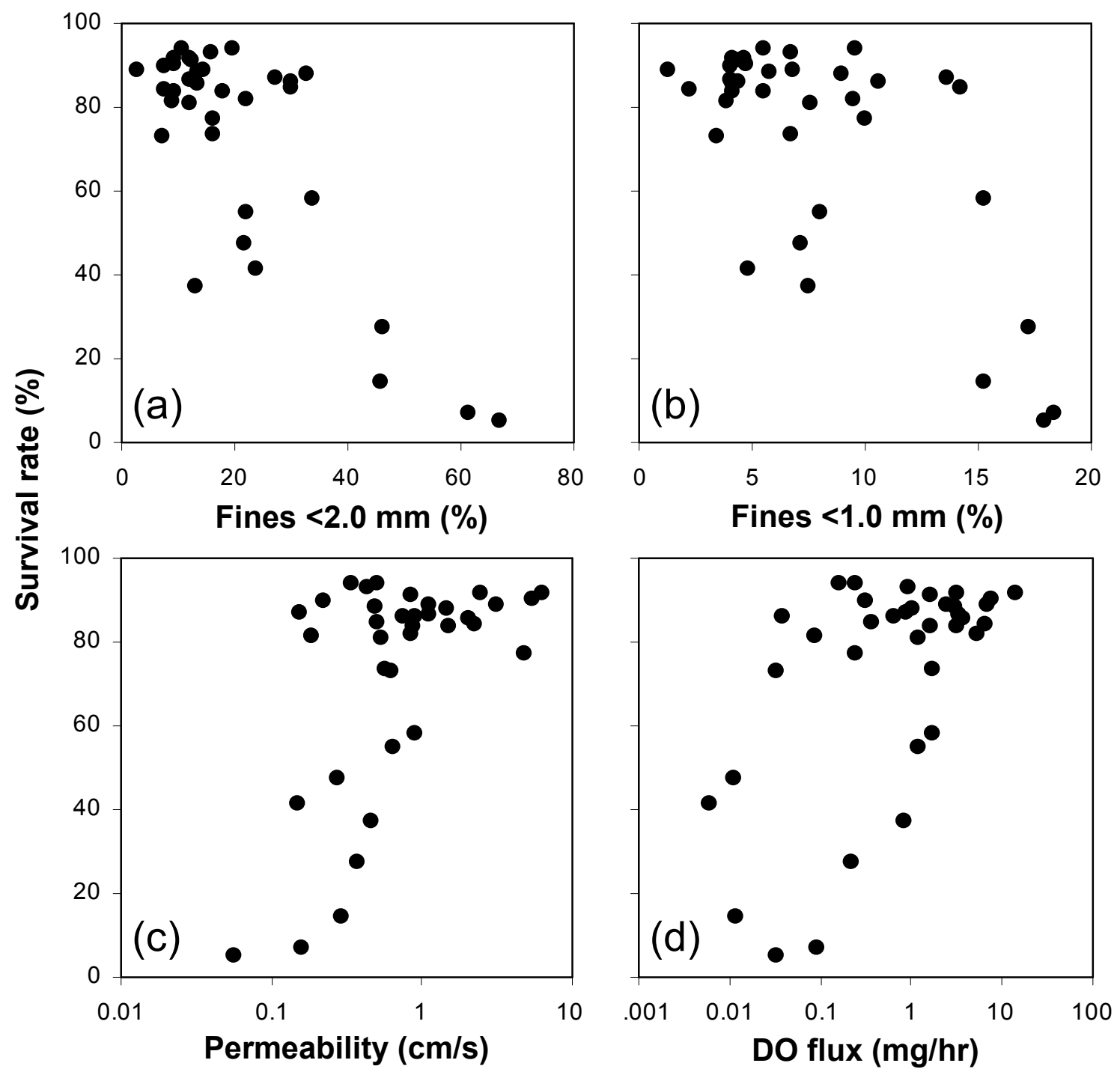

Fig. 6. Relation between survival rate of masu salmon embryo and cumulative weight percentage less than $2.0 \mathrm{~mm}$ (Fines $<2.0 \mathrm{~mm}$ ) (a) and $1.0 \mathrm{~mm}$ (Fines $<1.0 \mathrm{~mm}$ ) (b), permeability (c), DO flux (d). 
Appendix I. Hydraulic and water quality parameters with reference to embryo survival rate in the redds. "-" indicates no data. IWTL is intragravel water temperature which measured by data logger at centre site throughout the experimental period.

\begin{tabular}{|c|c|c|c|c|c|c|c|c|c|c|c|c|c|c|c|c|c|c|c|}
\hline \multirow[t]{2}{*}{ Site } & \multirow[t]{2}{*}{ Position } & \multicolumn{2}{|c|}{ Survival rate } & \multicolumn{2}{|c|}{$\begin{array}{l}\text { Permeability } \\
\qquad(\mathrm{cm} / \mathrm{s})\end{array}$} & \multicolumn{2}{|c|}{$\begin{array}{l}\text { Mean grain size } \\
(\mathrm{mm})\end{array}$} & \multicolumn{2}{|c|}{ IWTL $\left({ }^{\circ} \mathrm{C}\right)$} & \multicolumn{2}{|c|}{$\begin{array}{c}\text { Intragravel water } \\
\text { temp. }\left({ }^{\circ} \mathrm{C}\right)\end{array}$} & \multicolumn{2}{|c|}{$\begin{array}{c}\text { Intragravel DO } \\
(\mathrm{mg} / \mathrm{L})\end{array}$} & \multicolumn{2}{|c|}{ Intragravel pH } & \multicolumn{2}{|c|}{$\begin{array}{l}\text { Intragravel flow } \\
\text { rate }\left(\mathrm{cm}^{3} / \mathrm{hr}\right)\end{array}$} & \multicolumn{2}{|c|}{ DO flux (mg/hr) } \\
\hline & & Mean & SE & Mean & SE & Mean & SE & Mean & SE & Mean & SE & Mean & SE & Mean & SE & Mean & SE & Mean & SE \\
\hline \multirow{2}{*}{1} & Centre & 89.47 & 3.01 & 2.74 & 1.78 & 15.86 & 2.04 & 9.34 & 1.52 & 7.47 & 0.07 & 10.67 & 0.27 & 6.70 & 0.09 & 556.87 & 362.82 & 6.13 & 4.12 \\
\hline & Bank & 85.70 & 1.98 & 0.50 & 0.20 & 12.98 & 0.73 & - & - & 7.57 & 0.03 & 11.42 & 0.25 & 6.59 & 0.05 & 267.37 & 108.49 & 3.08 & 1.25 \\
\hline \multirow{2}{*}{2} & Centre & 86.16 & 2.68 & 1.61 & 0.80 & 16.41 & 4.72 & 9.33 & 1.54 & 9.13 & 0.03 & 11.01 & 0.09 & 6.84 & 0.02 & 327.61 & 163.71 & 3.58 & 1.77 \\
\hline & Bank & 90.62 & 0.60 & 2.69 & 1.50 & 19.56 & 1.65 & - & - & 9.27 & 0.12 & 10.76 & 0.21 & 6.86 & 0.01 & 340.00 & 189.16 & 3.67 & 2.08 \\
\hline \multirow{2}{*}{3} & Centre & 81.31 & 4.02 & 1.30 & 0.49 & 12.63 & 1.76 & 9.42 & 1.55 & 8.10 & 0.00 & 11.15 & 0.05 & 6.72 & 0.03 & 356.08 & 133.51 & 3.96 & 1.47 \\
\hline & Bank & 75.83 & 8.96 & 1.27 & 0.38 & 7.18 & 2.50 & - & - & 8.37 & 0.03 & 10.80 & 0.10 & 6.81 & 0.04 & 222.45 & 67.48 & 2.39 & 0.70 \\
\hline \multirow{2}{*}{4} & Centre & - & - & - & - & - & - & 9.40 & 1.62 & - & - & - & - & - & - & - & - & - & - \\
\hline & Bank & - & - & - & - & - & - & - & - & - & - & - & - & - & - & - & - & - & - \\
\hline \multirow{2}{*}{5} & Centre & 78.82 & 3.93 & 2.05 & 1.35 & 15.02 & 4.85 & 9.44 & 1.62 & 9.53 & 0.07 & 10.50 & 0.03 & 6.94 & 0.03 & 10.05 & 6.64 & 0.11 & 0.07 \\
\hline & Bank & 86.27 & 0.90 & 0.96 & 0.27 & 8.87 & 0.75 & - & - & 9.00 & 0.00 & 11.28 & 0.05 & 6.79 & 0.00 & 60.59 & 17.36 & 0.68 & 0.20 \\
\hline \multirow{2}{*}{6} & Centre & 61.14 & 15.95 & 0.66 & 0.11 & 7.88 & 1.07 & 9.51 & 1.63 & 9.47 & 0.09 & 10.26 & 0.15 & 6.88 & 0.02 & 120.23 & 20.45 & 1.24 & 0.23 \\
\hline & Bank & 13.15 & 7.19 & 0.20 & 0.09 & 2.95 & 0.85 & - & - & 9.47 & 0.12 & 10.34 & 0.10 & 6.89 & 0.00 & 10.96 & 5.21 & 0.11 & 0.05 \\
\hline \multirow{2}{*}{7} & Centre & 34.32 & 10.18 & 0.24 & 0.04 & 6.56 & 2.23 & 9.45 & 1.69 & 8.80 & 0.15 & 11.41 & 0.05 & 6.77 & 0.00 & 0.83 & 0.16 & 0.01 & 0.00 \\
\hline & Bank & - & - & - & - & - & - & - & - & - & - & - & - & - & - & - & - & - & - \\
\hline \multirow{2}{*}{8} & Centre & 89.63 & 4.22 & 0.35 & 0.09 & 14.87 & 2.11 & 9.59 & 1.70 & 7.63 & 0.03 & 13.48 & 0.05 & 6.85 & 0.05 & 12.21 & 3.31 & 0.17 & 0.05 \\
\hline & Bank & - & - & - & - & - & - & - & - & - & - & - & - & - & - & - & - & - & - \\
\hline
\end{tabular}

